\title{
Law Enforcement against Criminal Acts of Motorcycle Gangs Criminal of Rumbing \& Sharp Weapons
}

\author{
Johan Benbella Putra*) and Umar Ma'ruf ${ }^{* *}$ )
}

*) Student of Master of Law Program, Faculty of Law Universitas Islam Sultan Agung and Police member, email johanbanbella@gmail.com

${ }^{* *}$ Faculty of Law, Universitas Islam Sultan Agung Semarang

\begin{abstract}
.
The objectives of this study are as follows: To identify and analyze the factors that cause the gang attacks carried out by motorcycle gangs. To find out and analyzelaw enforcement against criminal offenses against motorbike gangs, perpetrators of beatings and sharp weapons.To find out and analyze obstacles and solutions in law enforcement against criminal offenses against motorbike gangs, perpetrators of beatings and sharp weapons. The approach to the problem that the writer uses in this legal research is included in juridicalempirical research, so what is examined initially is secondary data. This research is a descriptive research. Based on the results of this study, the factors that led to the gang attacking were carried out by motorcycle gangs, among others: a lack of understanding of the teenagers regarding the applicable provisions concerning the Traffic Law. Also caused as an influence on biological and psychological conditions. Biologically because they are in a period of growth and desire to show their existence to their peers and the environment. Law enforcement against criminal acts of beatings and carrying sharp weapons committed by motorcycle gang groups, namely by preventing and taking action. The obstacles are: The community, as a source of information about the occurrence of motorbike gangs, is afraid (skeptical) of the community about motorbike gangs, even though legal counseling has been carried out. The solution is: Coaching motorcycle gangs. Conducting legal education and prohibiting all acts of beating and carrying sharp weapons carried out by motorcycle gangs to the community.

Keywords: Law Enforcement; Crime; Beatings; Sharp Weapons.
\end{abstract}

\section{Introduction}

Indonesia is a rule of law (rechstaat), contained in Article 1 paragraph (3) of the 1945 Constitution of the Republic of Indonesia. Every action must be in accordance with the rule of law without exception. ${ }^{1}$ Law is a series of rules / regulations that control certain behavior and actions of human life in social life. ${ }^{2}$ The law does not require conflicts between individuals, it fills an honest and peaceful life in all levels of society. ${ }^{3}$ So that law is indispensable in a country to overcome the problems that occur in it in order to achieve a rule of law in the life of society, nation and state.

\footnotetext{
1 Asshiddiqie, Jimly. (2006). Konstitusi dan Konstitusionalisme Indonesia. Jakarta: Sekretariat Jenderal dan Kepaniteraan Mahkamah Konstitusi RI. p. 69.

2 Poernomo, Bambang. (1978). Asas-Asas Hukum Pidana. Yogyakarta: Ghalia Indonesia. p. 13

3 Sudarsono. (1995). Pengantar Ilmu Hukum. Cetakan ke-2. Jakarta: Rineka Cipta. p. 48.
} 
According to Sudarto, "One of the crimes that occur in society is crimes that use sharp weapons. The crime of committing an unpleasant act by using a sharp weapon. Crimes like these are very unsettling for society, causing insecurity for each of them. Crimes that occur like this are the impact of the loss of a social control system due to social changes that occur. Social change affects the social control system, and has an even deeper impact on deviation and crime. This crime is a human act ".4

In recent times the phenomenon of motorcycle gangs has become increasingly worrisome. This can especially be felt from the news published in print and online media. It is worrying because: 1) their existence seems to be increasingly widespread, especially in big cities and their surrounding areas; 2) the gang population is increasing; 3 ) their actions are considered to be increasingly reckless and brutal. This condition is a serious problem. In many cases their actions are not only limited to delinquency, violation of social norms and disturbing public order but have led to criminal acts, such as: assault of others, robbery, assault and murder.

There are two options for resolving conflicts that occur in the community, namely by means of litigation and non-litigation. The litigation channel is a way of solving problems through the Court, while non-litigation is a way of solving problems outside the Court. In the perspective of criminal law in Indonesia, the settlement of criminal cases outside the court is known, or often referred to as Alternative Dispute Resolution. This is pursued for restorative justice by balancing the actions of the perpetrator of the criminal act with the consequences. ${ }^{5}$

The purpose of this study is as follows: To find out and analyze the factors that lead to beatings carried out by motorcycle gangs To determine and analyze law enforcement against criminal offenses against motorbike gangs, perpetrators of beatings and sharp weapons.To find out and analyze obstacles and solutions in law enforcement against criminal offenses against motorbike gangs, perpetrators of beatings and sharp weapons

\section{Research methods}

The approach to the problem that the writer uses in this legal research is included in juridical-empirical research, so what is examined initially is secondary data. ${ }^{6}$ This research is a descriptive research that describes or describes and explains the object of research objectively that is related to the problem. Methods of data analysis obtained by qualitative analysis.

\footnotetext{
${ }^{4}$ Sudarto. (1986). Kapita Selekta Hukum Pidana. Bandung: Alumni. p. 107.

5 Arif Septria Hendra Saputra, Gunarto, Lathifah Hanim, Penerapan Restoratife Justice Sebagai Alternatif Penyelesaian Tindak Pidana Penganiayaan Di Satreskrim Polsek Lasem, Jurnal Daulat Hukum Vol. 1. No. 1 March 2018 ISSN: 2614-560X

${ }^{6}$ Soekanto, Soerjono. (2012). Pengantar Penelitian Hukum. Jakarta: Universitas Indonesia. p. 52.
} 


\section{Research Results and Discussion}

\subsection{The factors that led to the beatings carried out by motorcycle gangs}

The term "pengeroyokan" in the Criminal Code is not actually regulated, what is regulated in the Criminal Code is violence that is carried out jointly, openly / openly with collective energy where the perpetrator is more than one person which is carried out in public against people or goods / objects. , as regulated in Article 170 paragraph (1) to paragraph (3) of the Criminal Code.

Regarding the consequences of the joint violence act, a maximum imprisonment of seven (7) years if causing injuries, a maximum imprisonment of 9 (nine) years if causing serious injury as referred to in Article 90 of the Criminal Code, and criminal penalties. Maximum imprisonment of 12 (twelve) years if the loss of life is caused.

Basically, motorcycle gangs have no definite definition, but the author tries to define a motorcycle gang as a group of people or groups who use motorbikes as a unifier and usually lead to negative things. The term motorcycle gang always gives a bad image which is usually synonymous with anarchy. Lately, the motorcycle gang action has increasingly troubled the public, because their actions are not only a disturbance of public order, for example by carrying out illegal races but have developed into criminal acts such as robbery, robbery, vandalism, assault and even for committing murder. ${ }^{7}$

In an effort to deal with lawbreakers, criminologists are of the opinion that more comprehensive and comprehensive measures are needed. The important thing to do is to find the root of the problem that is more substantial. In the search for the causes of crime it is generally accepted that it is impossible to find only one factor which can explain both the causes of crime in general and of crimes in particular. What can be looked for are the factors in relation to a number of other factors that will produce crime. ${ }^{8}$

In the criminology literature there are also several factors that are very often associated with crime, although these factors need to be studied further to what extent have a causal relationship with crime. Several factors that are important to consider in the search for the causes of crime include: (a) Ecological theories regarding population density and social mobility; urban and rural; urbanization and urbanism; delinquency areas and housing; distribution according to age and sex; (b) In theories of cultural conflict, issues of ethnicity, religion, minority groups; (c) In economic theories, the effects of poverty and prosperity; (d) In the theory of differential association, mass media observers; (e) In anomie and subculture theory, the difference in values and norms between the "middle class" and "lower class". 9

\footnotetext{
${ }^{7}$ Asep Sunarsa, Attorney Role In Fighting Crimes Of Motorcycle Gang In Cirebon, Jurnal Daulat Hukum Volume 1 No. 2 June 2018 ISSN: 2614-560X

8 Bonger, W. A. (1995). Pengantar tentang Kriminologi. Pustaka Sarjana. Pembangunan. P. 29

${ }_{9}^{9}$ Reksodiputro, M. (1994). Mencari Faktor-Faktor Sebab Kejahatan, Pusat Pelayanan Keadilan Dan Pengabdian Hukum. Jakarta: Lembaga Kriminologi UI. p. 6
} 
The factors that led to the beatings carried out by motorcycle gangs included: lack of understanding of the teenagers regarding the applicable provisions regarding the Traffic law. Also caused as an influence on biological and psychological conditions. Biologically because they are in a period of growth and desire to show their existence to their peers and the environment. Meanwhile, the psychological development conditions of the perpetrators are faced with various unfavorable environmental conditions. This happens as a result of the changing development of society, both changes in the economic, social, cultural and social structures.

According to the author, the factors that led to the beatings carried out by motorbike gangs were analyzed by the theory of law enforcement that the laws and regulations. The possibility is that there is a mismatch in the laws and regulations regarding certain areas of life. Another possibility is the incompatibility of statutory regulations with unwritten law or customary law.

\subsection{Law Enforcement Against the Crime of Motorcycle Gangs as Criminal Offenders of beatings and Sharp Weapons}

The interaction of human life in society, as long as there is nothing in the course of life that goes straight, smoothly and safely. It can be seen in human life, whether disputes, crimes, injustice, discrimination, social inequalities and conflicts are the colors of the reality at hand. These problems are increasingly developing in other modifications due to the influence of increasingly sophisticated globalization technology. ${ }^{10}$

Humans also realize that peace and tranquility of life will not be achieved without self-awareness to change, improve behavior and morally support society. By nature, the essential thing of calm and tranquility can be achieved if the community provides a means of control, social supervision, whether in the form of written or unwritten regulations, institutions that apply sanctions, or forms of community agreement that carry out these functions. ${ }^{11}$

In line with this, efforts to create and build tranquility and tranquility must have a joint commitment to make changes starting from oneself and society in carrying out this control device. A crime will continue to multiply in society if it is only allowed without concern for enforcing the applicable law. The commitment or social contract from the community is then confirmed in the form of legal certainty.

Black track-recorded (black track records) on the brutal actions of motorcycle gang members make the public aware that the life of some young generations of the nation's hopes is very sad. Lately, the behavior of motorcycle gangs has increasingly troubled the community. News coverage in the media is always decorated with the criminal acts of people who carry out evil acts using motorbikes. Whoever is involved in it, anarchist action to take the lives of others is a crime that cannot be tolerated.

The criminal acts of motorcycle gangs have led to the anti-social category. The members of the motorcycle gang are considered to be trying to challenge the

${ }^{10}$ Saifullah. (2007). Refleksi Sosiologi Hukum Cet. I. Bandung: Rafika Aditama. p. 25.

11 Ibid 
established social structure that already exists. Indeed, there needs to be in-depth research for motorcycle gang crime.

Law enforcement against criminal acts of motorbike gangs, perpetrators of beatings and sharp weaponsnamely by prevention and enforcement. Prevention is carried out before the attacking incident occurs, while actions are taken after the attack by a motorcycle gang. Efforts to take action were carried out by means of the process of the applicable law, while prevention efforts were carried out before the incident took place. The sanctions given are still individual in nature.

Law enforcement against criminal acts of motorbike gangs, perpetrators of beatings and sharp weaponsanalyzed from the point of view by using law enforcement theory from the Islamic perspective that the enforcement of Islamic law is a tool aimed at changing the behavior of Muslim citizens. Based on legal science, law is the tool of social engineering. As a tool, of course the law cannot stand alone in regulating the behavior of the Muslim community.

\subsection{Inner barrier and solution Law Enforcement Against the Crime of Motorcycle Gangs as Criminal Offenders of beatings and Sharp Weapons}

Actions of violence that occur in the community are increasingly unsettling. In resolving a conflict or problem accompanied by acts of violence. In general, acts of violence can be defined as the deliberate use of physical force or force, actual threats or violence against oneself, other people, or against a group or community, which results in injury or is likely to injure, kill, psychologically endanger, or develop abnormalities. or loss. There are many forms of violence, including physical violence, verbal violence, psychological violence, economic violence, symbolic violence and neglect. Violence can be carried out by individuals or in groups, carelessly (in a state of urgency) or in an organized manner. ${ }^{12}$

Inner Barriers Law enforcement against criminal acts of motorbike gangs, perpetrators of beatings and sharp weapons among others:

- The community, as a source of information about the occurrence of motorbike gangs, is afraid (skeptical) of the community about motorcycle gangs, even though legal counseling has been carried out. The community is afraid of the risks they might experience if they report the actions of a motorcycle gang that they have experienced or are aware of.

- The difficulty in tracking down motorcycle gangs is due to the lack of information networks about motorcycle gang actions. Information about motorbike gang networks is often cut off at the lower level, making it difficult to trace further.

- Even though the motorcycle gangs have disbanded with their own awareness, there are still motorcycle gangs that have formed their own association under the name of the big motorcycle gangs.

- Lack of infrastructure or equipment to provide counseling for the Police when conducting counseling such as in focus, sound system or audio visual, and from

\footnotetext{
12 Aan Hardiansyah, Akhmad Khisni, Jawade Hafidz, Tindak Pidana Kekerasan Dalam Proses Belajar Mengajar Ditinjau Dari Perspektif Hukum Pidana Dan Undang-Undang Nomor 14 Tahun 2005 Tentang Guru Dan Dosen, Jurnal Daulat Hukum Vol. 1. No. 1 March 2018 ISSN: 2614-560X
} 
the Regional Government there has been no collaboration in the form of support. So that budget constraints have not fully touched schools that are far away because of motorcycle gangs.

Solutions to overcome obstacles in Law enforcement against criminal acts of motorbike gangs, perpetrators of beatings and sharp weapons among others:

- Coaching for motorcycle gangs is carried out

- holding legal counseling and prohibiting all acts of beating and carrying sharp weapons carried out by motorcycle gangs to the community.

- Creating systems and programs that aim to punish motorcycle gang members who behave negatively. For groups of motorbike delinquents who are proven to have committed a criminal act, law enforcement efforts are made.

Inner barrier and solution Law enforcement against criminal acts of motorbike gangs, perpetrators of beatings and sharp weaponsreviewed from the point of view of crime prevention theory that the high rate of crime, then indirectly encourages the development of reaction to crime and the perpetrators and in essence related to the aims and objectives of the crime prevention effort. Crime prevention efforts have been made by all parties, both government and society in general. Various programs and activities have been carried out while continuing to look for the most appropriate and effective way to overcome these problems.

\section{Closing}

The factors that led to the beatings carried out by motorcycle gangs included: lack of understanding of the teenagers regarding the applicable provisions regarding the Traffic law. Also caused as an influence on biological and psychological conditions. Biologically because they are in a period of growth and desire to show their existence to their peers and the environment. Law enforcement against criminal acts of beatings and carrying sharp weapons committed by motorcycle gang groups, namely by preventing and taking action. Prevention is carried out before the attacking incident occurs, while actions are taken after the attack by a motorcycle gang. Efforts to take action were carried out by means of the process of the applicable law, while prevention efforts were carried out before the incident took place. The sanctions given are still individual in nature.

The obstacles are: The community as a source of information about the occurrence of motorbike gangs is afraid (skeptical) of the community towards motorcycle gangs, even though legal counseling has been carried out. The difficulty in tracking down motorcycle gangs is due to the lack of information networks about motorcycle gang actions. Even though the motorcycle gangs have disbanded with their own awareness, there are still motorcycle gangs that have formed their own association under the name of the big motorcycle gangs.

The solution is: Coaching motorcycle gangs. Conducting legal education and prohibiting all acts of beating and carrying sharp weapons carried out by motorcycle gangs to the community. Creating systems and programs that aim to punish motorcycle gang members who behave negatively. For groups of motorbike 
delinquents who are proven to have committed a criminal act, law enforcement efforts are made.

Furthermore suggested that For police officers, they must increase the number of personnel for security, regardless of the number of tickets sold or the estimated number of supporters who will come to support their clubs as a precautionary measure in order to overcome all forms of riots that arise. A clear legal arrangement is needed, even if it is necessary for the criminal act of beating supporters, a regulation is formed specifically to make it more detailed and clarify what actions can later have the potential as a criminal act of football supporters; Law enforcement against the football supporter riot, which is a criminal act that occurred in Yogyakarta, is still not running optimally, because the club of the supporters who attacked it cannot be processed.

\section{References}

\section{Journals:}

[1] Aan Hardiansyah, Akhmad Khisni, Jawade Hafidz, Tindak Pidana Kekerasan Dalam Proses Belajar Mengajar Ditinjau Dari Perspektif Hukum Pidana Dan Undang-Undang Nomor 14 Tahun 2005 Tentang Guru Dan Dosen, Jurnal Daulat Hukum Vol. 1. No. 1 March 2018 ISSN: 2614-560X, Unissula

[2] Arif Septria Hendra Saputra, Gunarto, Lathifah Hanim, Penerapan Restoratife Justice Sebagai Alternatif Penyelesaian Tindak Pidana Penganiayaan Di Satreskrim Polsek Lasem, Jurnal Daulat Hukum Vol. 1. No. 1 March 2018 ISSN: 2614-560X, Unissula

[3] Asep Sunarsa, Attorney Role In Fighting Crimes Of Motorcycle Gang In Cirebon, Jurnal Daulat Hukum Volume 1 No. 2 June 2018 ISSN: 2614-560X, Unissula

\section{Books:}

[1] Asshiddiqie, Jimly. (2006). Konstitusi dan Konstitusionalisme Indonesia. Jakarta: Sekretariat Jenderal dan Kepaniteraan Mahkamah Konstitusi RI.

[2] Asshiddiqie, Jimly. (2006). Konstitusi dan Konstitusionalisme Indonesia. Jakarta: Sekretariat Jenderal dan Kepaniteraan Mahkamah Konstitusi RI.

[3] Bonger, W. A. (1995). Pengantar tentang Kriminologi. Pustaka Sarjana. Pembangunan.

[4] Poernomo, Bambang. (1978). Asas-Asas Hukum Pidana. Yogyakarta: Ghalia Indonesia.

[5] Reksodiputro, M. (1994). Mencari Faktor-Faktor Sebab Kejahatan, Pusat Pelayanan Keadilan Dan Pengabdian Hukum. Jakarta: Lembaga Kriminologi UI.

[6] Saifullah. (2007). Refleksi Sosiologi Hukum Cet. I. Bandung: Rafika Aditama.

[7] Soekanto, Soerjono. (2012). Pengantar Penelitian Hukum. Jakarta: Universitas Indonesia.

[8] Sudarsono. (1995). Pengantar Ilmu Hukum. Cetakan ke-2. Jakarta: Rineka Cipta.

[9] Sudarto. (1986). Kapita Selekta Hukum Pidana. Bandung: Alumni. 